\title{
Structure and optical properties of CdS polycrystalline layers for solar cells based on CdS/CdTe
}

\author{
G.S.Khrypunov, G.I.Kopach, A.I.Dobrozhan, \\ R.P.Mygushchenko, O.V.Kropachek, V.M.Lyubov \\ National Technical University "Kharkiv Polytechnic Institute", 2 \\ Kirpichov Str., 61002 Kharkiv, Ukraine
}

Received July 23, 2018

Thin CdS films about 200-500 nm thick with stable hexagonal modification with 85-80\% transparency value respectively in the visible and infrared spectrum regions were investigated. The use of the FTO sublayer to obtain heterosystem glass/FTO/CdS by magnetron sputtering does not affect the phase composition of the cadmium sulfide layer and the width of the band gap $\left(E_{g}=2.42-2.44 \mathrm{eV}\right)$. Cadmium sulfide thin films, obtained by direct current magnetron sputtering, can be used as a layer of a wide window layer in thin-film solar cells based on the CdS/CdTe heterosystem.

Keywords: cadmium sulfide, direct current magnetron sputtering, thin films, structures, optical properties.

Исследованы тонкие пленки CdS толщиной порядка 200-500 нм устойчивой гексагональной модификации с прозрачностью в областях видимого и инфракрасного спектра 85-80 \% соответственно. Использование подслоя FTO для получения гетеросистем стекло/FTO/CdS магнетронным распылением не влияет на фазовый состав слоя и ширину запрещенной зоны $\left(E_{g}=2,42-2,44\right.$ эВ) сульфида кадмия. Тонкие пленки сульфида кадмия, полученные магнетронным распылением на постоянном токе, могут быть использованы в качестве слоя широкозонного окна в тонкопленочных солнечных элементах на основе гетеросистемы CdS/CdTe.

Структура і оптичні властивості полікристалічних шарів CdS для фотоперетворювачів на основі CdS/CdTe. Г.С.Хрипунов, Г.І.Копач, А.І.Доброжан, Р.П.Мигущенко, О.Ю.Кропачек, В.М.Любов.

Досліджено тонкі плівки CdS товщиною порядку 200-500 нм стабільної гексагональної модифікації зі значенням коефіцієнта прозорості 85-80 \% відповідно у видимій та інфрачервоній області спектра. Використання підшару FTO для отримання гетеросистем скло/FTO/CdS магнетронним розпиленням на постійному струмі не впливає на фазовий склад шару сульфіду кадмію та значення ширини забороненої зони матеріалу $\left(E_{g}=2,42-2,44 \mathrm{eV}\right)$. Тонкі плівки сульфіду кадмію, отримані методом магнетронного розпилення на постійному струмі, можуть бути використані в якості шару широкозонного вікна у тонкоплівкових сонячних елементах на основі гетеросистеми CdS/CdTe.

\section{Introduction}

Thin-film solar cells based on $n-\mathrm{CdS} / p-$ CdTe heterostructure are prospective for an industrial production [1-4]. In such solar cells cadmium sulfide layer is used as a window layer. Cadmium sulfide band gap is $E_{g}=2.42 \mathrm{eV}$. This fact make possible transparance in the visible part of the solar light spectrum and the solar light can penetrate into the CdTe base layer. It allows to reduce a negative impact of surface recom- 
bination of nonequilibrium charge carriers by removing their active generation area from the illuminated surface. One of the economical and high-tech methods for thin films obtaining is magnetron sputtering [5]. The thin films deposition sputtering technology is a scalable technique with some good features: small distance between source and target, lower substrate temperatures and low vacuum. Generally radiofrequency sputtering is used for semiconductors or insulators since it avoids the electrical charging of the target. For this reason another possibility is to use direct current pulsed sputtering where the voltage is fixed, but pulsed in time to avoid charging [6]. There are some technological problems during the deposition of semiconductor films by direct current magnetron sputtering (DC magnetron sputtering). In the CdS sputtering process they are caused by low conductivity of cadmium sulfide pressed powder targets and sufficiently low emission ability of this material. Therefore, the influence of physical and technological mode of condensation by DC magnetron sputtering on the crystal structure and optical properties of grown CdS thin films was studied.

\section{Experimental}

In laboratory technology of condensation CdS thin films by DC magnetron sputtering the design of VUP-5m magnetron was used, which feature was that the cooling circuit covers only the magnetic system. As the result that there was no forced cooling of sputtered semiconductor pressed powder target. The target was made by cold pressing from cadmium sulfide powder. For the implementation of the process of thermionic emission of electrons from the pressed powder target for plasma discharge ignition the target was preheated for 10-15 min.

In laboratory technology of condensation CdS nanoscale thin films at glass substrates and also at glass substrates with FTO $\left(\mathrm{SnO}_{2}: \mathrm{F}\right)$ sublayer by DC magnetron sputtering the design of VUP-5m magnetron was used. The physical and technology condensation modes were different: substrate temperature $T_{s u b}=120-150^{\circ} \mathrm{C}$, pressure of inert gas $P_{\mathrm{Ar}}=0.9-1 \mathrm{~Pa}$, magnetron discharge current density $J=1.1 \mathrm{~mA} / \mathrm{cm}^{2}$, the voltage on magnetron $V=350-400 \mathrm{~V}$, deposition time 5 or $15 \mathrm{~min}$. The CdS layers thickness depended on deposition time only.

The structure of obtained CdS films was studied by X-ray diffractometry methods
[7]. Automatic X-ray spectra were recorded at $\theta-2 \theta$ using X-ray diffractometer DRON-4 with a step 0.01-0.02 degree in $\mathrm{K}_{\alpha}$-radiation of a molybdenum anode.

Optical studies of CdS, CdTe layers and CdS/CdTe heterosystems were conducted using the spectrometer SF-2000. The transmission spectrum of studied films was used to determine the thickness of the layers according to [8]. The thickness of the layers was determined by the formula:

$$
t=\frac{M \cdot \lambda_{1} \cdot \lambda_{2}}{2\left(n\left(\lambda_{1}\right) \cdot \lambda_{2}-n\left(\lambda_{2}\right) \cdot \lambda_{1}\right)},
$$

where $M-$ multiplier, which indicates the order of the interference points of extremums (interference maxima or minima of the transmission spectrum); $\lambda_{1}, \lambda_{2}-$ the wavelengths of two adjacent extremums (interferential maxima or minima of transmission spectrum) in $\mathrm{nm} ; n\left(\lambda_{1}\right), n\left(\lambda_{2}\right)-$ refractive index, depending on the wavelength $\lambda_{1}, \lambda_{2}$. The method allows to set the thin film thickness with a $9 \%$ error.

The bandgap of thin films and heterosystems were determined by calculating the dependence of absorption coefficient on the wavelength $\alpha(\lambda)$ using [9]:

$$
T=(1-R) \cdot e^{-\alpha \cdot t},
$$

where $T$ - transmission coefficient; $R-$ reflection coefficient; $t-$ film thickness.

The CdS bandgaps in polycrystalline films were determined by extrapolation of the linear portion of the $(\alpha \cdot h v)^{2}=f(h v)$ curves (where $h$ - Planck constant, $v-$ frequency) to the intersection with the $h v$ energy axis. The method allows us to set the optical bandgap of the material with a $10 \%$ error.

\section{Results and discussion}

XRD studies of CdS layers crystalline structure of different thicknesses shows that for all obtained FTO/CdS heterosystems we can see peak at angle $2 \theta=21.42^{\circ}$ (Fig. 1). This peak corresponds to the reflection (103) of stable hexagonal phase of CdS (Fig. 1a).

The results of XRD processing are shown in the Table 1 . The XDR studies of crystal structure of CdS layers (Fig. 1b) with deposition time $\tau_{\kappa}=15 \mathrm{~min}$ show that there are reflections for (101), (102) and (105). They belong to a hexagonal modification of CdS 

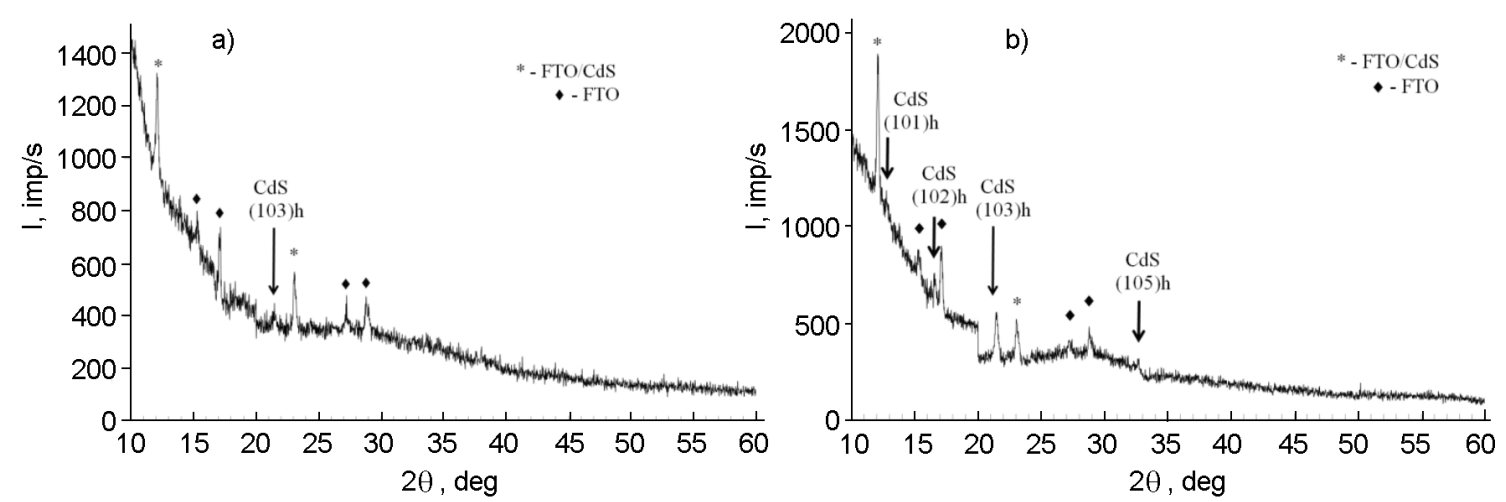

Fig. 1. XRD of FTO/CdS heterosystems obtained at different condensation time: a) $\tau_{\mathrm{K}}=5 \mathrm{~min}$, b) $\tau_{\kappa}=15 \mathrm{~min}$.

and this suggests that these CdS films on FTO sublayer have a crystal directed texture (103). Estimated values of interplanar spacing were $a=4.15(75) \AA, \quad c=$ $6,75(26) \AA$ range. The obtained values of the parameter are less than $1 \%$ different from tabular values for cadmium sulfide hexagonal modification (PCPDFWIN \#411049). In the sample with deposition time $\tau_{\kappa}=5$ min in Fig. 1a, reflections (101), (102) and (105) are not visible because the sample thickness is about three times less than the thickness of the sample with deposition time $\tau_{\kappa}=15 \mathrm{~min}$, whose XRD is shown in Fig. 1b. It is known that the number and intensity of peaks of a particular phase on an XRD depends on the amount of material in a thin film [7].

Based on the conclusions of previous studies [10], in which it is described that cadmium sulfide thin films on glass substrate condensed with a deposition time $\tau_{\kappa}=$ 5-15 min have a stable hexagonal modification. It can be argued that the presence FTO sublayer for obtain FTO/CdS heterosystems by DC magnetron sputtering does not affect the phase composition of the cadmium sulfide layer. In the case of a thicker CdS layer $\left(\tau_{\kappa}=15 \mathrm{~min}\right)$, decrease of the full width at half maximum (FWHM) of the

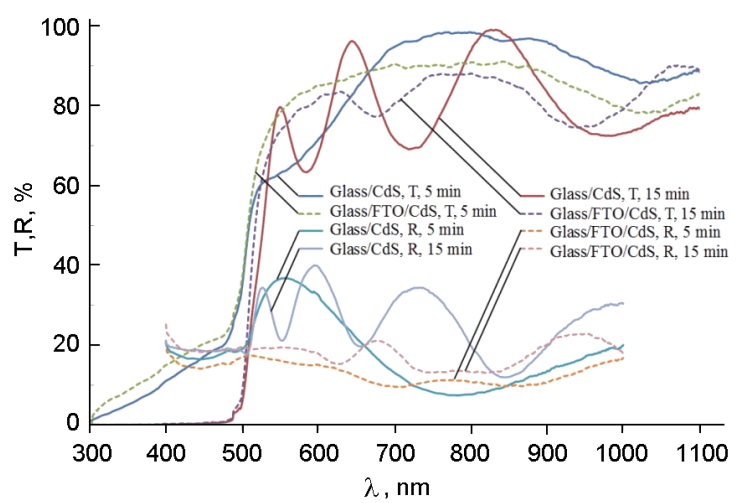

Fig. 2. Optical transmittance $(T, \%)$ and reflection $(R, \%)$ spectra for CdS films of different thicknesses.

(103) peak on $2 \theta$ scale relative to a similar value for CdS ( $\left.\tau_{\kappa}=5 \mathrm{~min}\right)$ sample indicates an grain size increase with increase thickness of the polycrystalline CdS film in the FTO/CdS heterosystem.

In the Fig. 2 the optical transmittance and reflection spectra of CdS obtained layers are shown.

The optical transmittance for 180$200 \mathrm{~nm}\left(\tau_{\kappa}=5 \mathrm{~min}\right)$ thick films in wavelengths range $\lambda=300-500 \mathrm{~nm}$ is less than $20 \%$ and in wavelengths range $\lambda=550-$ $1100 \mathrm{~nm}$ is $85-90 \%$. For $540 \mathrm{~nm}\left(\tau_{\kappa}=\right.$ $15 \mathrm{~min})$ thick films the optical transmit-

Table. The processing results of XRD of CdS films

\begin{tabular}{|c|c|c|c|c|c||}
\hline \multirow{2}{*}{$\tau_{\kappa}, \min$} & $\begin{array}{c}\text { Peak position, } \\
\text { degrees }\end{array}$ & $\begin{array}{c}\text { Interplanar } \\
\text { spacing, }\end{array}$ & $h k l$ & Intensity, imp/s & FWHM, degrees \\
\hline 5 & 21,42 & 1.91 & $(103)$ & 31.59 & 0.33 \\
\hline \multirow{2}{*}{15} & 12.78 & 3.19 & $(101)$ & 54.05 & 0.12 \\
\cline { 2 - 6 } & 16.56 & 2.46 & $(102)$ & 96.28 & 0.12 \\
\cline { 2 - 6 } & 21.42 & 1.91 & $(103)$ & 178.20 & 0.22 \\
\cline { 2 - 6 } & 32.64 & 1.26 & $(105)$ & 44.92 & 0.19 \\
\hline
\end{tabular}




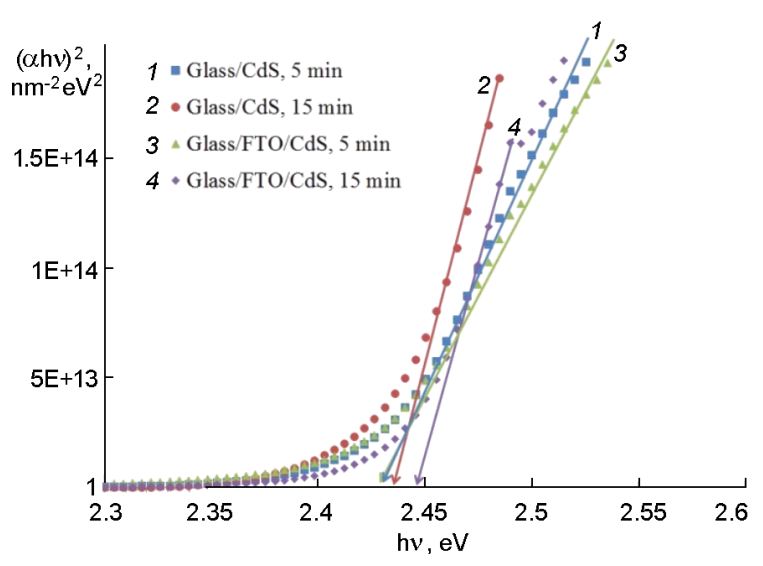

Fig. 3. $(\alpha \cdot h v)^{2}=f(h v)$ Dependences for CdS films of different thicknesses.

tance in wavelengths range $\lambda=300-500 \mathrm{~nm}$ is up to $3 \%$ and in wavelengths range $\lambda=$ $550-1100 \mathrm{~nm}$ is $85 \%$. Average optical reflection for CdS films of different thicknesses in FTO/CdS heterosystems is $15 \%$ and for glass/CdS structure is 10-25\% in studied wavelengths range 400-1000 nm. Calculated condensation speed of CdS layers is about $35 \mathrm{~nm} / \mathrm{min}$ and absolute refractive index is $n=2.23-2.39$. In Fig. $3(\alpha \cdot h v)^{2}=$ $f(h v)$ dependences to determine bandgap of CdS films in obtained samples of different thicknesses. The bandgap of different samples is $E_{g}=2.42-2.44 \mathrm{eV}$ which is close to values for CdS monocrystals ( $E_{g}=2.42-$ $2.45 \mathrm{eV}$ ). The data obtained allow us to assert that CdS films condensed by DC magnetron sputtering method could be used as wide bandgap window layer in thin-film solar cells based on CdS/CdTe heterosystems.

In Fig. 4 graph of the calculated absorption coefficient for studied CdS films in infrared spectra is shown.

The results of optical studies of CdS films of $540 \mathrm{~nm}$ thickness shown the absorption coefficient $\alpha$ in infrared spectra is $7 \cdot 10^{6}-1.2 \cdot 10^{7} \mathrm{~nm}^{-1}$. This information could be used in production of infrared sensors based on such layers.

\section{Conclusions}

The laboratory method of DC magnetron sputtering with preheating of the target allows to receive cadmium sulfide film of various thicknesses (200-500 nm varying the condensation time) with a deposition rate of $35 \mathrm{~nm} / \mathrm{min}$ was developed. The physical and technology condensation modes were different: substrate temperature $T_{s u b}=120-$ $150^{\circ} \mathrm{C}$, pressure of inert gas $P_{\mathrm{Ar}}=0.9-1 \mathrm{~Pa}$, magnetron discharge current density $J=$

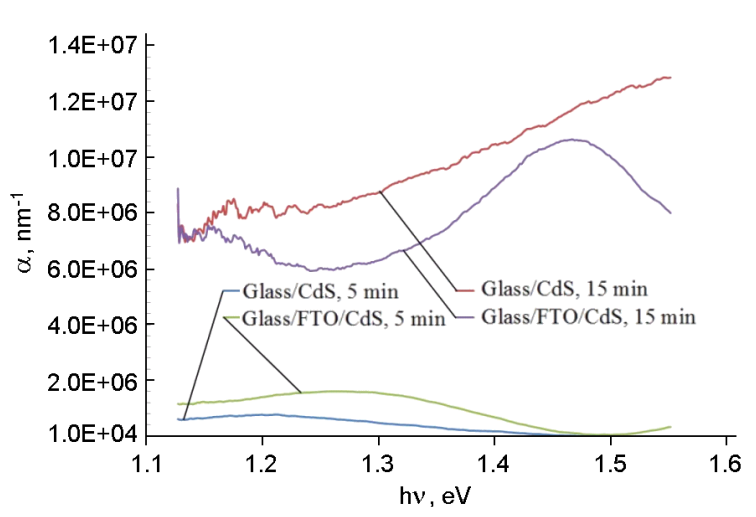

Fig. 4. Dependences of the absorption coefficient in infrared spectra for CdS films of different thicknesses.

$1.1 \mathrm{~mA} / \mathrm{cm}^{2}$, the voltage on magnetron $V=$ $350-400 \mathrm{~V}$.

The obtained polycrystalline CdS thin films with a thickness of about $200 \mathrm{~nm}$ of stable hexagonal modification with high values of the transparency coefficient in the visible and infrared spectrum regions can be used as a wide-window layer in thin-film solar cells based on the CdS/CdTe heterosystem. Using the FTO sublayer to obtain glass/FTO/CdS heterosystem by DC magnetron sputtering does not affect the phase composition of the cadmium sulfide layer. The absorption coefficient dependence character in infrared spectrum region in cadmium sulfide films of different thicknesses suggests that CdS layers with a more than $500 \mathrm{~nm}$ thickness can be used in infrared radiation sensors.

\section{References}

1. A.Bosio, N.Romeo, S.Mazzamuto et al., Prog. Cryst. Growth Charact.Mater., 52, 247 (2006).

2. M.Hadrich, C.Heisler, U.Reislohner et al., Thin Solid Films, 519, 7156 (2011).

3. X.Wu, Solar Energy, 96, 803 (2004).

4. X.Wu, J.C.Keane, R.G.Dhere et al., in: Proc. 17th Europ. Photovoltaic Solar Energy Conf., Munich, Germany (2001), p.995.

5. H.Li, X.Liu, Solar Energy, 115, 603 (2015).

6. N.Romeo, A.Bosio, Tedeschi et al., Sol.Energy Mater. Sol.Cells, 58, 209 (1999).

7. D.M.Vasilyev, Diffraction Methods for Structural Studies, Metallurgy, Moscow (1977) [in Russian].

8. V.V.Brus, M.N.Solovan, E.V.Maystruk et al., Sov. Phys. Solid State, 56, 1886 (2014).

9. A.M.Salem, M.E.El-Ghazzawi, Semicond.Sci. Technol., 19, 236 (2004).

10. G.I.Kopach, R.P.Mygushchenko, G.S.Khrypunov et al., J.Nano-Electron.Phys., 9, 05035 (2017). 